\title{
TEACHING ENGLISH FOR MEDICAL PURPOSES - FROM THEORY TO PRACTICE: CHALLENGES ENCOUNTERED IN ELT AT SECONDARY LEVEL
}

\section{Valentina Gavranović}

Singidunum University,

Belgrade, Serbia

Correspondence:

Valentina Gavranović

e-mail:

vgavranovic@singidunum.ac.rs

\begin{abstract}
:
This paper analyses the current educational framework for foreign language teaching in secondary schools in Serbia, with the focus on teaching medical English viewed from the perspective of English for Specific Purposes principles. The aim of this work is to define these principles and present their development and changes within ESP theory and practice ever since it was incepted in the 1960s, and to investigate how much of these principles is present in the official documents regulating teaching foreign languages in secondary vocational schools for health care workers. The purpose of this work is to identify the areas which could be improved, and to propose solutions how to implement ESP methods and techniques in teaching medical English to secondary school students.
\end{abstract}

Keywords:

EMP, secondary level, teacher's role, learner-centred approach.

\section{INTRODUCTION}

The domain of applied linguistics has been considerably expanded for the last several decades not only due to the new insights in linguistic theory, but also the constant social and cultural changes. As a consequence of complex changes affecting modern society, educational establishments are looking for new ways in organising meaningful and purposeful teaching and learning processes, relying on knowledge and practices from different areas of human existence. The role and place of foreign languages in educational systems, particularly the English language, has also been changed, and, subsequently, new models and methods have been proposed in order to face these demands in adequate and effective ways. With the rise of economy, commerce and more intertwined and global world we are living in, the purpose for learning the English language has also been altered. One of the current pedagogical imperatives in teaching English as a foreign language is to make a shift from the languagecentered to the leaner-centered approach, and this is the main premise in a branch of applied linguistics called English for Specific Purposes (ESP). Although, in the past, ESP courses were typically designed for intermediate and advanced adult students, mainly at tertiary level, nowadays, there is a growing number of students attending ESP courses at an earlier 
age and at a lower level of proficiency. Classes designed according to the ESP principles is exactly what students attending vocational schools in Serbia need.

This paper provides a theoretical framework for ESP, its development and current trends. It investigates the presence of its postulates in the official curriculum, accredited coursebooks, and standards prescribed for the English language teaching in secondary vocational schools in Serbia, with a focus on teaching medical English. The aim of this paper is to get a critical insight into teaching English for Medical Purposes (EMP) at secondary level, and specify the crucial role a teacher has in this language teaching paradigm.

\section{THE DEVELOPMENT OF ESP}

ESP, as a branch of applied linguistics, emerged in the 1960s as an immediate response to a newly created social, economic and cultural environment [1]. When it became clear that students could not manage to deal with real-life situations they were encountering after finishing English language courses, the need for specialised courses was clearly defined [2].

Over the years, the main principles of ESP changed, and different methods were proposed. At first, the main aim of ESP was the language itself, and little or no attention was given to the development of language skills. Teaching revolved around lexical explanations of technical and scientific terms, and it was text-based. In the late 1970s, the attention of ESP was moved away from the language-focused approach to the learner-centered approach, with the focus on a leaner and his specific foreign language needs [1]. In the centre of the teaching and learning process was a learner and his needs, and therefore it was not enough only to take into consideration how language worked, but also how leaners acquired language which would be used in real life situations. Therefore, needs analysis gained in importance, and it represented the starting point for creating and organising language learning processes. The emphasis was on the development of all language skills - reading, writing, speaking and listening - which could be used in specific discourses. ESP was consolidated in the 1980s with the influential papers written by Hutchinson and Waters [3]. Hutchinson did not dismiss the languagecentred approach entirely, but emphasised the importance of the learning process, students' specific needs, their experience, subject matter knowledge and skills, different learning styles, and material development, stating that "if it is to have any real and lasting value, ESP must be founded in the first instance on sound principles of learning, and it is with this purpose in view that we have proposed a learning-centered approach to ESP [4]." Over the last two decades, the ESP principles gained in popularity, and the importance of ESP in language teaching can be proved by the ever-growing number of articles published in internationally acclaimed scientific magazines, and various conferences dealing with this issue are held around the world [5]. Javid [6] also reports that the number of universities around the world offering ESP courses is on the rise.

Nowadays, there are opposing views whether to position ESP as a distinct field, independent of the older discipline of English for General Purposes (EGP), or to consider them as complementing principles which can contribute with their own methods and techniques in different learning situations. Dudley-Evans and St Jones insist on the idea that these two disciplines should not be completely separated, and suggest that ESP should be viewed as a discipline that is "designed to meet specific needs of the learner", and it "makes use of the underlying methodology and activities of the discipline it serves [7]."

ESP does not rely only on the principles and methods of applied linguistics, but it is also dependent on the postulates of the field it is related to. Therefore, it has developed its own methodology. Dudley-Evans [7] points out to two aspects of ESP methodology: one reflecting the methodology of applied linguistics, with a slightly changed role of teachers and students, and the other referring to the methodology and principles of the disciplines and professions it is related to.

ESP courses are traditionally designed for adult intermediate or advanced learners. However, ESP is "quite flexible discipline [6]" and due to the constant changes affecting society, and the emerging needs of learners, ESP courses are now also created for younger learners with the basic knowledge of the language, or even for the beginners. Today, what characterizes ESP is a diversity of its forms and applications, with different areas growing in response to the needs of English language learners. Depending on the specific needs of the learners, ESP has been divided into English for Academic Purposes (EAP) and English for Occupational Purposes (EOP). The latter has been divided into English for Professional Purposes (EPP), and one of its disciplines being English for Medical Purposes (EMP). 


\section{THE IMPORTANCE OF TEACHING EMP IN SECONDARY SCHOOLS}

Secondary vocational schools in Serbia provide education in specific fields, and upon graduation students are awarded a vocational qualification certificate, which offers them the opportunity to start working in the field they were trained for, or to continue their schooling at a tertiary level. A very important segment of vocational education implies health care education, and in Serbia there are about 33 secondary schools providing education and training for over 20,000 students in different fields of medicine: nursing, midwifery, dentistry, physiotherapy, pharmacy, beauty care, etc. The new reforms of secondary vocational schools imply more training and practical work for students, at the expense of the number of classes devoted to general subjects and theory. The aim of these reforms is to educate a health care worker who will be qualified to start working immediately upon graduation, or develop their skills and knowledge at some higher education institution: college of academic studies or college of vocational studies, the latter being a more common option for many students.

Schooling lasts for either four or three years, and only one foreign language (mainly English) is taught for four or two years, respectively. Due to the fact that the majority of students either start working upon graduation, or go to a college of vocational studies (which does not provide any language course), we come to the conclusion that the only medical English they get in their formal schooling is during secondary school education. The implication of this fact is very important in creating and organising English language classes at secondary level.

\section{THE ANALYSIS OF THE CURRENT FOREIGN LANGUAGE TEACHING FRAMEWORK}

The analysis of the official documents which regulate the content and aims of English language teaching in secondary vocational schools shows a considerable lack of the main ESP principles.

First of all, the curriculum is the same for all vocational schools, and it comprises aims and tasks which primarily reflect the needs of students who will use English for general purposes. It is also packed with grammatical sections and various general topics. The analysis of the curriculum shows that only one topic, out of 15 stated, is related to the use of professional English. The curriculum also prescribes the main aims and tasks of foreign language teaching, and only one, out of 6 formulated, refers to the use of professional English, but in very broad terms - students are supposed to read the texts which will help them keep up to date with the information and innovations in their profession [8]. The text-based approach instruction reflects the early principles advocated in ESP in the 1960s, which have been superseded by many other relevant aspects and approaches.

Another official document which regulates teaching foreign languages at secondary level is a compilation of standards which instruct teachers what is relevant and what students are expected to know upon graduation [9]. The adoption of these standards implies the final standardisation of knowledge, skills and competences which students need to develop before 'pre-university' education [10]. The very mentioning of 'university' in standards at secondary level shows a certain level of neglect of vocational students' needs. Furthermore, there is no explicitly stated descriptor which refers particularly to professional/ vocational competences.

Another very important guideline for teachers teaching in vocational schools is a coursebook, which for many represents the main source and material used in the classroom. The analysis of coursebooks accredited by the Ministry of Education shows a list of titles predominantly aimed at teaching English for General Purposes.

Taking into consideration the current educational framework, and the presence/ absence of ESP principles in the official documents which regulate teaching foreign languages at secondary level in Serbia, we can conclude that teachers have a very demanding task to respect what is prescribed, but also to incorporate professional English in their lessons. What is needed to achieve this is a trained and qualified language teacher who is well equipped with the main principles of teaching both general and professional English.

\section{PERSPECTIVES ON DESIGNING AN EMP COURSE}

Teaching EMP at tertiary level in Serbia has been a subject of research of different authors, who approached the issue from various aspects, defining the main principles of EMP [11], or analysing students' needs and expectations [12]. However, the area of teaching EMP in secondary schools has not been researched yet, and we have not found any published work analysing various aspects of teaching medical English for nurses or other health care workers. 
Teaching medical English in secondary schools imposes various challenges on language teachers, because it involves many areas, and it is constantly growing [2]. Teacher's role is crucial in organising purposeful and meaningful lessons for students, preparing them for real life everyday situations, but also equipping them with skills and competences required at workplace.

Teaching EMP should be based on a serious analysis of learner's needs, and lessons need to be devised according to the recognised needs. Lessons should be organised around selected topics, contents and functions, and teachers should think of various activities which will help learners develop all four skills. The selection of teaching techniques and materials should rely on the results of the needs analysis [3]. Dudley suggests that a teacher, during the preparatory stage, needs to ask the following key questions: What is the main aim of learning English? What are students' needs? Which skills do they need to improve and how well? Which receptive and which productive skills do they need to master, and how well? These questions provide "a reasoned basis for the subsequent processes of syllabus design, materials writing, classroom teaching and evaluation [4]."

The methodology of teaching English for Medical Purposes is distinguished from the principles and methodologies used when teaching English for General Purposes, and it implies different approaches to teaching. First of all, students who are being educated and trained to be health care workers upon graduating from secondary school have different learning aims than those students who plan to go to some university and continue formal schooling. Teaching English to these students must be viewed within this context, and their learning needs represent a very important starting point in designing and organising lessons. Apart from helping students gain basic communication skills for everyday life contexts, teachers have a crucial role in recognising their students' special needs. Teachers can easily neglect various complex aspects of teaching EMP if they rely only on the official curriculum, which is very detailed when it comes to teaching general English, but rather vague and does not precisely define what and, which is more important, how something should be taught.

Teaching EMP implies teachers' rather autonomous work in syllabus design and material selection. Since EMP teachers teach students who are bound to work in hospitals, the language they need to use is related to healthcare. Selected material, tasks and activities used in classes should cater for students' professional needs. Developing students' communicative skills in the target language is one of the main aims of EMP, and it can be achieved through various activities, such as role plays, simulation, presentations, passing on information, case studies [12]. EMP lessons should simulate workplace conditions, where communication between the healthcare worker and patients, or other health care worker is of vital importance. The commonest types of communication are found in the following situations: asking for and giving information in different contexts, explaining various medical procedures, asking about medical history, talking about symptoms, patients' feelings, handovers, etc. Students are valuable resource for planning these lessons, because they can choose those situations which they have already experienced. The language used in communication is that found in General English context, but also includes healthcare terminology.

Apart from enhancing communication skills, students also need to develop other language skills. Writing activities and tasks should focus on practical matters, such as writing hospital documents, charts, patients' records [2]. Designing activities which can help students develop their listening skills is also important in EMP, and teachers have the task to incorporate various audio or video materials in their lessons, providing students with authentic healthcare contexts. Vocabulary used in lessons is a mix of medical terminology and everyday health terms, and it must be carefully selected. Reading medical texts is relevant, but the approach to teaching EMP solely based on text-analysis was superseded long time ago.

A very important part of preparing and designing EMP lesson refers to the selection of material used in teaching. Dudley argues that ESP is "a material-led" field. Due to the absence of accredited coursebooks dealing with medical issues, language teachers are forced to find, select and adapt material to their students' needs and level of knowledge. Dudley defines the new role of ESP language teacher with the term "material provider", because the task of an ESP teacher is really demanding: finding the appropriate material, adapting it if necessary, or even writing some additional material in order to cater for students' needs [7].

Another role that an ESP teacher needs to take on is that of a collaborator, due to the fact that in many cases ESP learners may know more about the subject matter than the teacher himself. Therefore, there is an extra burden imposed on teachers, whereby they are not only expected to master teaching skills, but also to have a good insight into the content they are teaching, as well as methodologies used in the relevant area of interest. ESP 
teachers are required to be familiar with different teaching methods and approaches, and to use them flexibly and creatively depending on the teaching situations and students' needs. The question that always arises in EMP context is how much a language teacher should know about the subject matter. Nowadays, it a common belief that teachers are supposed to have a solid knowledge in methodology and pedagogy, but also to understand the specific needs of their students, and what their future profession involves. EMP teachers are not required to be experts in different areas of medicine, but they should know the main principles of the discipline, and show an active interest in the area they teach. Students are valuable resources in ESP contexts, and it is advisable to negotiate with them about the plan and content of the course. This new role of a teacher provides a dynamic process of mutual teaching and learning, and calls for a very professional and "personal sensitivity from the teacher [13]." Hutchinson even uses the term "practitioner" for an ESP teacher.

Very often EMP teachers do not teach only language skills, but professional skills as well. They include various skills health care workers need to show at workplace, such as communication with patients, different types of conversations with colleagues and other health care workers. Through EMP lessons students can also become aware of the importance of developing skills relying on their social and emotional intelligence. EMP teachers should also help students find the appropriate way and vocabulary how to deal with patients who are in very sensitive and delicate situations, and this aspect of their job is of vital importance due to the very specific nature of their profession. In EMP context, language skills are integrated with medical skills, and such contextualisation helps learners view language learning as meaningful and purposeful [13]. The integrated approach can also improve student's language skills, but also consolidate or even broaden their subject matter knowledge and social skills necessary for their future profession.

\section{FUTURE TRENDS AND DIRECTIONS}

ESP, and EMP as a branch of it, is a field of applied linguistics which is gaining in importance in ELT around the world. The analysis of the current situation in education system in Serbia shows the lack of clearly defined aims and principles of its application at secondary level. Not only do official documents regulating what is to be taught in secondary vocational schools lack clear content and aims of teaching English for Specific Purposes, but there is not any research or study analysing the issue and dealing with this important aspect of foreign language teaching. The effectiveness of application of the main principles of ESP largely depends on teachers' knowledge, skills and openness to change perspective from teaching EGP to teaching ESP.

In order to make teachers aware of the importance of applying ESP methodology in secondary vocational schools, it is important in the first place to educate teachers systematically in their formal education, namely, ESP methodology should be introduced as an important part of methodology course which English language students have at universities. Many teachers upon graduating from faculties are not prepared for ESP contexts, and hold to the main principles of methodology of English for General Purposes they were exposed to during their own education. Another important support ESP teachers can get is through various forms of professional development, but, again, there is a considerable gap in the offer of seminars and conferences dealing with this issue in Serbia.

\section{CONCLUSION}

Ever since its inception in the 1960s, ESP has gone through several major shifts in theory and practice from the language-centred approach to the learner-centred approach. The new trends in ELT show that ESP is gaining in popularity due to the fact that there has been an increase in various vocational courses and trainings throughout the world. With the spread of globalisation, English is being used in different professional contexts, and, therefore, the purpose of learning it has also been changed. Many educational institutions worldwide readily respond to the newly created circumstances, analysing learners' needs, and creating language courses which primarily focus on a learner and his aims for learning the language. This paper analysed the current framework for learning English in secondary medical schools, and it focused on the official documents which regulate what should be taught in vocational schools. This study showed a considerable lack of clearly defined principles for teaching EMP, and that the main focus in the curriculum and standards is on general English. If we take into consideration the fact that many of these students will finish with formal education with secondary school (or go to a college of vocational training where students are not offered any language course), we can conclude that the only medical English lessons they 
have are at secondary level. This fact contributes to the thesis that Medical English should be taken more seriously in secondary schools, and that EMP teachers need the institutional support to devise and organise their lessons as effectively as possible.

\section{REFERENCES}

[1] C.G.Ramirez, "English for Specific Purposes: Brief History and Definitions," Revista de Lenguas Modernas, vol. 23, pp. 397-386, 2015.

[2] V. Allum, Teaching English for Medical Purposes, Cambridge: Cambridge University Press, 2012.

[3] T. Dudley-Evans, "English for specific purposes," in Teaching English to speakers of other languages, R. Carter and D. Nunan, Eds. Cambridge: Cambridge University Press, 2001.

[4] T. Hutchinson, A. Waters, English for specific purposes: a learning-centred approach. Cambridge: Cambridge University Press, 2010.

[5] A. Pradhan, "English for Specific Purposes: Research Trends, Issues and Controversies," English for Specific Purposes World, vol. 14, pp. 1-13, 2013.

[6] C.Z.Javid, "English for Specific Purposes: Role of Learners, Teachers and Teaching Methodologies," European Scientific Journal, vol. 11, pp. 17-34, 2015.

[7] T. Dudley-Evans, M J. St John, Developments in English for Specific Purposes, A multi-disciplinary approach. Cambridge: Cambridge University Press, 2012.
[8] Nacionalni prosvetni savet, Pravilnik o izmenama Pravilnika o planu o programu obrazovanja i vaspitanja za zajedničke predmete u stručnim i umetničkim školam, Službeni glasnik RS, br.3/2015.

[9] Nacionalni prosvetni savet, Pravilnik o opštim standardima postignuća za kraj opšteg srednjeg obrazovanja i srednjeg stručnog obrazovanja u delu opšteobrazovnih predmeta, Službeni glasnik RS, br. 117, 2013.

[10] J. N. Tomić, Opšti standardi postignuća za kraj opšteg srednjeg $i$ srednjeg stručnog obrazovanja $i$ vaspitanja u delu opšteobrazovnih predmeta, Za predmet strani jezik, Priručnik za nastavnike. Beograd: Zavod za vrednovanje kvaliteta obrazovanja i vaspitanja, 2015.

[11] N. Milosavljevic, A. Vuletic, Lj, Jovkovic, "Learning Medical English: A Prerequisite for Successful Academic and Professional Education," Language of Medicine, vol. 143, pp. 237-240, 2015.

[12] Z. Antic, "Towards Uniformity in English for Medical Purposes: Evaluation and Design," Language of Medicine, vol. 137, pp. 454-457, 2009.

[13] Z. Antic, "The Options for Teacher Cooperation in English for Medical Purposes," Scientific Online Resource System, pp. 495-501, 2017. [Online]. Available: http://press.mu-varna.bg/ojs/index.php/conf/ article/view/4028. [Accessed March 10, 2018]. 